\title{
EFFECTS OF INJECTION OF HYPERTONIC GLUCOSE ON METABOLISM OF WATER AND ELECTROLYTES IN PATIENTS WITH EDEMA ${ }^{1}$
}

\author{
By ROBERT TARAIL, 2,3 DONALD W. SELDIN,4 AND ALLAN V. N. GOODYER 3 \\ (From the Department of Internal Medicine, Yale University School of Medicine, and the \\ Medical Service of the New Haven Hospital, New Haven, Conn.)
}

(Submitted for publication June 13, 1951; accepted July 30, 1951)

In normal human subjects, rapid injection of hypertonic glucose produces severe hyperglycemia which elevates the effective osmotic pressure of the extracellular fluid, thereby withdrawing water from cells, expanding extracellular volume, and decreasing the concentration of serum sodium (1). Large amounts of salt as well as water are excreted in the urine as intense glycosuria supervenes $(1,2)$. Similar effects have been demonstrated with a variety of nonelectrolytes, predominantly sugars of small molecular size (1-6). The reasons for these accelerated urinary losses of salt and water are not clear. They have usually been ascribed to the osmotic influence within the renal tubules of that fraction of the injected solute which appears in the urine (2-6).

The following study of the effects of injections of hypertonic glucose in edematous cardiacs and cirrhotics was undertaken for two reasons: 1) To determine whether this procedure might have therapeutic value in facilitating the delivery of edema or ascites ;2) To determine by comparison with normal subjects whether a different physiological background, which includes a great propensity toward renal retention of salt (7), conditions the response of the body fluids and kidney to osmotic loads.

\section{METHODS AND CALCULATIONS}

Chemical methods were identical with those previously reported $(1,3,8)$, except that serum glucose was usually

1 Read by title at the 42 nd annual meeting of the American Society for Clinical Investigation, May, 1950.

2 This work was done during the tenure of a Life Insurance Medical Research Fellowship.

8 Present address: Department of Research Medicine, University of Pittsburgh School of Medicine, Pittsburgh, Pa.

4 Present address: Department of Medicine, Southwestern Medical College of the University of Texas, Dallas, Texas.

- Markle Scholar in Medical Science. determined directly rather than estimated from the concentration of glucose in whole blood.

Balance data were calculated using methods and assumptions previously described from this department (1, 8). Changes in extracellular volume were estimated from alterations in the chloride balance after assuming an initial extracellular volume of $35 \%$ of the body weight. Balance periods, designated in Table II, represent intervals between withdrawals of specimens of blood. These periods, therefore, may include several collections of urine which are listed individually in Table $\mathrm{I}$.

\section{EXPERIMENTAL PROCEDURE}

The subjects of the experiments were seven patients with severe edema, which in four (A. B., T. L., J. R., M. S.) was primarily related to cirrhosis of the liver and in three (J. W., R. J., L.) was cardiac in origin (Table I). One patient (L., Table I) had well-controlled diabetes. All patients had been maintained on a low-salt diet containing less than $1 \mathrm{gm}$. of salt per day for at least five days prior to the study. Those patients with congestive heart failure had been digitalized, and other diuretic measures such as bed rest and mercurials had been successful in only two patients of the seven. J. W. was given a mercurial 48 hours before the injection of glucose, with an excellent response; $L$. had been losing weight slowly as a result of bed rest, a salt-free diet, and readjustment of the dosage of digitalis.

The experiments were performed while the patients were thirsting (dehydration) or taking water (hydration). In the three dehydration experiments, food and fluid were withheld for 12 to 16 hours, after which control urines and bloods were obtained and a rapid infusion of hypertonic glucose was begun. The volume and concentration of the glucose solutions, as well as their rate of administration, are listed separately for each patient in Table I. Specimens of blood were then obtained at the time of voidings, shortly following cessation of the infusion, and on one or two occasions thereafter. Subjects were recumbent throughout the experiment. The same general procedure was followed in the four hydration experiments, except that the subjects ingested 150 to $300 \mathrm{cc}$. of tap water per hour for eight hours prior to and during the injection of glucose. R. J., however, was unable to drink water after the start of the infusion because of nausea. Mannitol clearance (presumably a measure of glomerular filtration rate) and para-aminohippurate clear- 


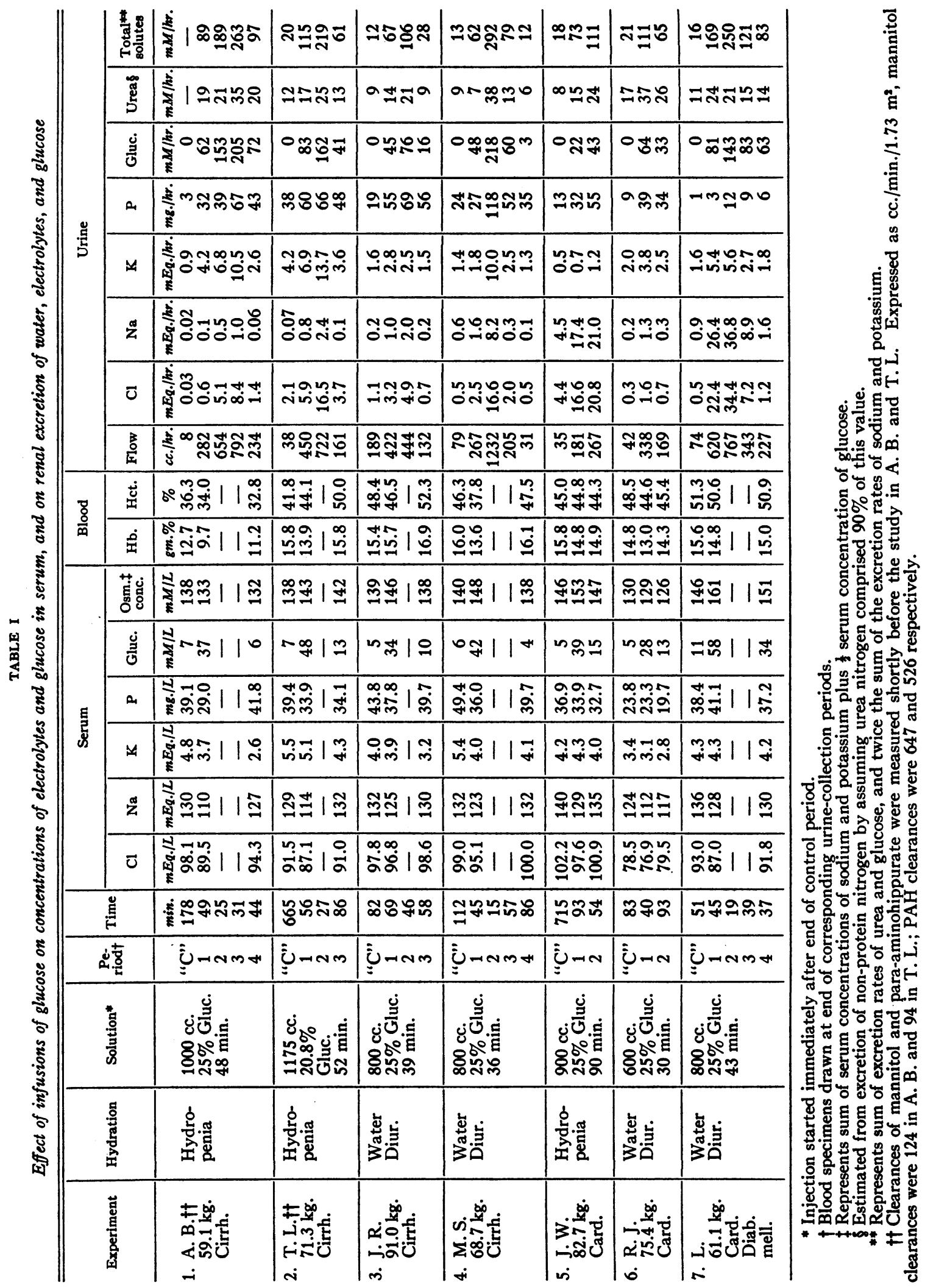


ance (presumably a measure of renal plasma flow) were measured in two subjects (A. B. and T. L.) shortly before this study.

Painful muscular cramps of the extremities occurred within one hour following the infusion in the three hydropenic subjects. These spasms were accompanied by paresthesiae and, in one instance, by painful hyperperistalsis. These phenomena persisted for several hours but did not occur in hydrated subjects. It is noteworthy that the rapid intravenous injection of hypertonic solutions into decompensated cardiacs did not produce any respiratory distress, although mild transient dyspnea was noted at the end of the infusion given to J. R. who had cirrhosis.

\section{RESULTS}

Analytical and derived data are presented in Tables I and II and in Figures 1-3.

Serum and urine during the control period (Table I). The concentration of serum sodium was low initially in five patients (A. B., T. L., J. R., M. S., R. J.), ranging from 123.7 to 132.2 $\mathrm{mEq} . / \mathrm{L}$. The serum chloride was within the nor-

6 The low concentration of serum sodium was presumably a consequence of renal retention of water in excess of salt. This reduction was not the result of urinary losses of salt, since only negligible amounts were excreted during the control period as well as during other, unrecorded, periods of study. Extrarenal losses of salt could not be

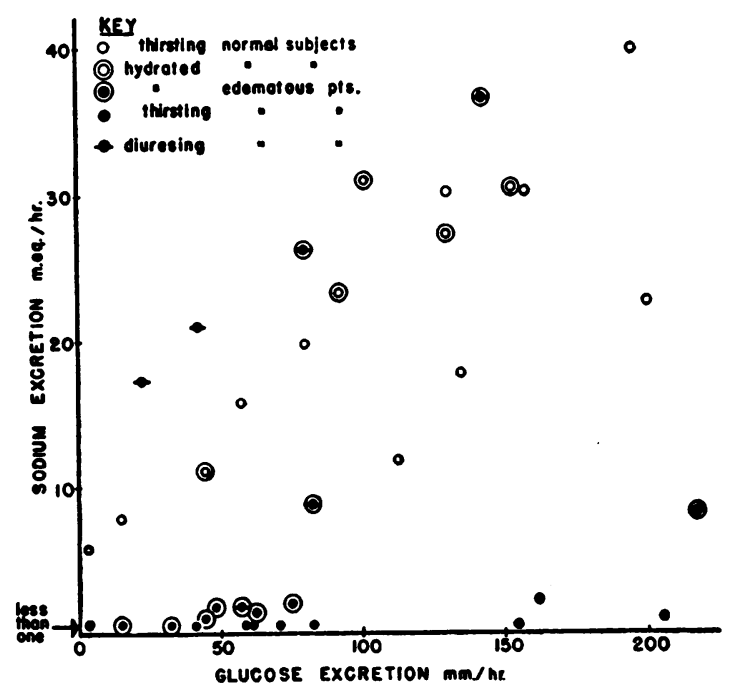

Fig. 1. The Relationship between Glucose Excretion and Sodium Excretion during Glucose Diuresis in Various SUbjects

Note that the rates of sodium excretion were corrected for the initial rates prior to the administration of glucose. (Note also that a semi-solid circle with a horizontal bar indicates a value obtained in a diuresing, hydrated, edematous patient [L.].)

implicated, since there was no vomiting, diarrhea, or undue sweating.

TABLE II

Balances of electrolytes and glucose; changes in distribution of body water

\begin{tabular}{|c|c|c|c|c|c|c|c|c|c|c|c|c|c|c|c|c|c|}
\hline \multirow{2}{*}{$\begin{array}{l}\text { Experiment, } \\
\text { Subject. } \\
\text { Wt. }\end{array}$} & \multirow{2}{*}{$\begin{array}{l}\text { Balance } \\
\text { period* }\end{array}$} & \multicolumn{5}{|c|}{ External balancet } & \multicolumn{3}{|c|}{ Change in volume } & \multicolumn{4}{|c|}{ Extracellular balance } & \multicolumn{4}{|c|}{ Intracellular balance } \\
\hline & & $\mathrm{Cl}$ & $\mathrm{Na}$ & $\mathbf{K}$ & $\mathbf{P}$ & Gluc. & $\begin{array}{l}\text { Extra- } \\
\text { cell. }\end{array}$ & $\begin{array}{l}\text { Intra- } \\
\text { cell. }\end{array}$ & $\begin{array}{l}\text { Plas- } \\
\text { ma }^{* \neq}\end{array}$ & $\mathrm{Na}$ & $\mathbf{K}$ & $\mathbf{P}$ & Gluc. & $\mathbf{N a}$ & $\mathbf{K}$ & $\mathbf{P}$ & Gluc.t† \\
\hline 1. $\begin{array}{l}\text { A. B. } \\
59.1 \mathrm{~kg} .\end{array}$ & $\begin{array}{l}\mathbf{A} \\
\mathbf{B}\end{array}$ & $\begin{array}{r}m E q . \\
-3 \\
-10 \\
\end{array}$ & $\begin{array}{r}m E q . \\
-3 \\
-4 \\
\end{array}$ & $\begin{array}{l}m E q . \\
-4 \\
-10 \\
\end{array}$ & $\begin{aligned} & \text { mg. } \\
&- 26 \\
&- 68 \\
&\end{aligned}$ & $\begin{array}{r}g m . \\
+241 \\
-40 \\
\end{array}$ & $\begin{array}{r}\text { liters } \\
+1.9 \\
-1.2 \\
\end{array}$ & $\begin{array}{l}\text { livers } \\
-1.2 \\
+0.3 \\
\end{array}$ & $\begin{array}{r}\% \\
+36 \\
-12 \\
\end{array}$ & $\begin{array}{r}m E q \\
-195 \\
+205 \\
\end{array}$ & $\begin{array}{l}m E q . \\
-16 \\
-28 \\
\end{array}$ & $\begin{array}{r}\text { ms. } \\
-150 \\
+237 \\
\end{array}$ & $\begin{array}{r}8 m . \\
+123 \\
-128 \\
\end{array}$ & $\begin{array}{r}m E q . \\
+192 \\
-209 \\
\end{array}$ & $\begin{array}{r}m E q . \\
+12 \\
+18 \\
\end{array}$ & $\begin{array}{r}\text { mg. } \\
+124 \\
-319 \\
\end{array}$ & $\begin{array}{l}g m . \\
+118 \\
+88 \\
\end{array}$ \\
\hline 2. $\mathrm{T}_{71.3 \mathrm{~kg} .} \mathrm{L}$ & A & $\begin{array}{r}-9 \\
-19 \\
\end{array}$ & $\begin{array}{l}-5 \\
=9\end{array}$ & $\begin{array}{l}-6 \\
-11\end{array}$ & $\begin{array}{l}-56 \\
-98 \\
\end{array}$ & $\begin{array}{r}+231 \\
-24 \\
\end{array}$ & & $\begin{array}{r}-0.7 \\
+1.0 \\
\end{array}$ & $\begin{array}{l} \pm 9 \\
-23\end{array}$ & $\begin{array}{r}-230 \\
+280 \\
\end{array}$ & $\begin{array}{l}-3 \\
-28 \\
\end{array}$ & $\begin{array}{r}-90 \\
-49 \\
\end{array}$ & $\begin{array}{r}+196 \\
-168 \\
\end{array}$ & $\begin{array}{r}+225 \\
-289 \\
\end{array}$ & $\begin{array}{r}-3 \\
+17\end{array}$ & $\begin{array}{l} \pm 34 \\
-49 \\
\end{array}$ & $\begin{array}{r}+35 \\
+144 \\
\end{array}$ \\
\hline 3. J. R. & $\begin{array}{l}\text { A } \\
\text { B }\end{array}$ & $\begin{array}{l}-7 \\
-7\end{array}$ & $\begin{array}{l}-4 \\
-5\end{array}$ & $\begin{array}{l}-3 \\
-3\end{array}$ & $\begin{array}{l}-64 \\
-107 \\
\end{array}$ & $\begin{array}{r}+191 \\
-13 \\
\end{array}$ & $\begin{array}{l}+0.2 \\
-0.6 \\
\end{array}$ & $\begin{array}{r}+0.1 \\
+0.7 \\
\end{array}$ & $\begin{array}{l} \pm 2 \\
-17 \\
\end{array}$ & $\begin{array}{r}-250 \\
+130 \\
\end{array}$ & $\begin{array}{l}-2 \\
-25 \\
\end{array}$ & $\begin{array}{r}-185 \\
+\quad 38 \\
\end{array}$ & $\begin{array}{r}+164 \\
-141 \\
\end{array}$ & $\begin{array}{l}+246 \\
-135 \\
\end{array}$ & $\begin{array}{l}-1 \\
+22\end{array}$ & $\begin{array}{l}+121 \\
-145\end{array}$ & $\begin{array}{r}+27 \\
+128 \\
\end{array}$ \\
\hline 4. M.S. & $\begin{array}{l}\text { A } \\
\text { B }\end{array}$ & $\begin{array}{r}-5 \\
-10 \\
\end{array}$ & $\begin{array}{l}-4 \\
-5 \\
\end{array}$ & $\begin{array}{l}-1 \\
-6 \\
\end{array}$ & $\begin{array}{r}-20 \\
-129 \\
\end{array}$ & $\begin{array}{r}+194 \\
-21 \\
\end{array}$ & $\begin{array}{r}+0.9 \\
-1.3 \\
\end{array}$ & $\begin{array}{r}-0.4 \\
+1.4 \\
\end{array}$ & $\begin{array}{l}+36 \\
-29 \\
\end{array}$ & $\begin{array}{r}-90 \\
+150 \\
\end{array}$ & $\begin{array}{l}-30 \\
-3 \\
\end{array}$ & $\begin{array}{r}-292 \\
+40 \\
\end{array}$ & $\begin{array}{r}+165 \\
-173 \\
\end{array}$ & $\begin{array}{l} \pm 86 \\
-155 \\
\end{array}$ & $\begin{array}{r}+29 \\
-3 \\
\end{array}$ & $\begin{array}{l}+272 \\
-169\end{array}$ & $\begin{array}{r}-29 \\
+152\end{array}$ \\
\hline 5. $\mathrm{J}_{82.7} \mathrm{~W}$ kg. & $\begin{array}{l}\text { A } \\
\text { B }\end{array}$ & $\begin{array}{l}-29 \\
-22 \\
\end{array}$ & $\begin{array}{l}-31 \\
-23\end{array}$ & $\begin{array}{l}-1 \\
-1\end{array}$ & $\begin{array}{r}-50 \\
-49 \\
\end{array}$ & $\begin{array}{r}+219 \\
-\quad 7 \\
\end{array}$ & $\begin{array}{l} \pm 1.1 \\
-1.1 \\
\end{array}$ & $\begin{array}{l}-0.5 \\
+0.8 \\
\end{array}$ & $\begin{array}{r}+7 \\
0 \\
\end{array}$ & $\begin{array}{r}98 \\
+51 \\
\end{array}$ & $\begin{array}{r} \pm 8 \\
-13 \\
\end{array}$ & $\begin{array}{r}5 \\
-57 \\
\end{array}$ & $\begin{array}{r}+178 \\
-128 \\
\end{array}$ & $\begin{array}{r}+67 \\
\pm \quad 74 \\
\end{array}$ & $\begin{array}{r}-9 \\
+12 \\
\end{array}$ & $\begin{array}{r}-45 \\
+\quad 8 \\
\end{array}$ & $\begin{array}{l}+41 \\
+121 \\
\end{array}$ \\
\hline 6. R. J. & A & $\begin{array}{l}-5 \\
-3 \\
\end{array}$ & $\begin{array}{l}-7 \\
-3 \\
\end{array}$ & $\begin{array}{l}-3 \\
-4 \\
\end{array}$ & $\begin{array}{l}-26 \\
-52 \\
\end{array}$ & $\begin{array}{r}+142 \\
-\quad 9 \\
\end{array}$ & $\begin{array}{r}+1.1 \\
-1.5 \\
\end{array}$ & $\begin{array}{r}-0.8 \\
+1.2 \\
\end{array}$ & $\begin{array}{r}+20 \\
-10 \\
\end{array}$ & $\begin{array}{r}-130 \\
-90 \\
\end{array}$ & $\begin{array}{r}-5 \\
-8 \\
\end{array}$ & $\begin{array}{r}+96 \\
-212 \\
\end{array}$ & $\begin{array}{r}+115 \\
-80 \\
\end{array}$ & $\begin{array}{r}+123 \\
+87 \\
\end{array}$ & $\begin{array}{r}+2 \\
+4 \\
\end{array}$ & $\begin{array}{r}-122 \\
+160 \\
\end{array}$ & $\begin{array}{r}+27 \\
+71 \\
\end{array}$ \\
\hline 7. $\mathrm{L}_{61.1 \mathrm{~kg} .}$ & $\begin{array}{l}\text { A } \\
\text { B }\end{array}$ & $\begin{array}{l}-18 \\
-18\end{array}$ & $\begin{array}{l}-22 \\
-22\end{array}$ & $=4$ & $=2$ & $\begin{array}{r}+189 \\
-25\end{array}$ & \pm 1.3 & $\begin{array}{l}-1.0 \\
+1.5\end{array}$ & $\begin{array}{l} \pm 7 \\
-2\end{array}$ & $\begin{array}{l}-10 \\
-135\end{array}$ & $\begin{array}{l} \pm 6 \\
-8\end{array}$ & $\begin{array}{r}+110 \\
-140\end{array}$ & $\begin{array}{r}+195 \\
-104\end{array}$ & $\begin{array}{l}-12 \\
+113\end{array}$ & $\begin{array}{l}-10 \\
+3\end{array}$ & $\begin{array}{l}-112 \\
+127\end{array}$ & $\overline{+}{ }_{79}^{6}$ \\
\hline
\end{tabular}

* Balance data are expressed per individual balance period rather than cumulatively. Duration of balance period is the interval between withdrawal of blood specimens, as shown in Table I.

$\dagger$ Balance of chloride and sodium are corrected for small quantities lost in serum drawn for analysis.

¥ Calculated from changes in chloride balance after assuming initial extracellular volume of $35 \%$ of body weight.

8 Estimated from measured oral and intravenous intake and urinary excretion of water, the calculated changes in extracellular volume, and assumed insensible water loss at the rate of $40 \mathrm{cc}$. $/ \mathrm{hr}$. Since water of oxidation comprised less than $100 \mathrm{cc}$. per balance period, it was not included.

** Estimated from changes in hematocrit and in hemoglobin concentration.

t† Positive intracellular balances of glucose represent utilization or storage. 


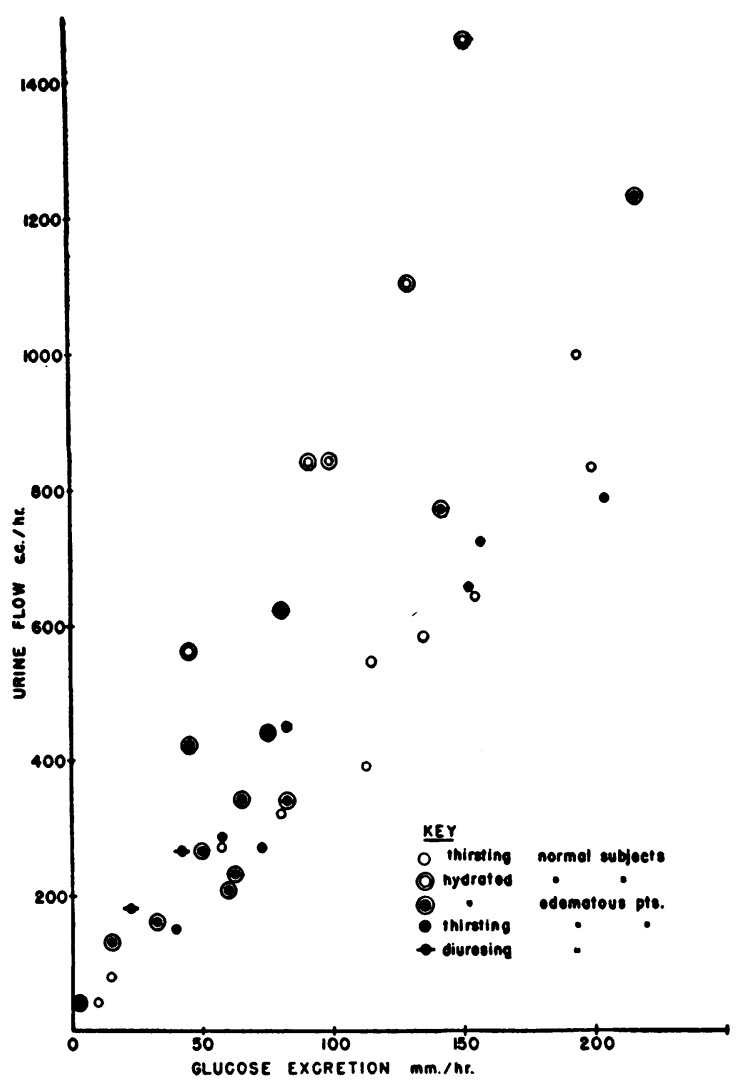

Fig. 2. The Relationship between Glucose ExCREtion aNd URINe Flow dURING Glucose DiUResis IN VARIOUS SUbJects

See legend of Figure 1 for significance of semi-solid circle with horizontal bar.

mal range or slightly low in three of these patients (A. B., J. R., M. S.), reduced in proportion to sodium in one (T. L.), and disproportionately reduced in R. J., a severely decompensated cardiac with primary respiratory $\mathrm{CO}_{2}$ retention. The serum sodium was normal only in the patients who had responded to diuretic measures before the study period (see Procedure). Initial concentrations of serum potassium and inorganic phosphorus were slightly depressed in $R$. J. probably because of impairment of appetite and low intake of potassium and phosphorus.

The urine contained negligible amounts of sodium and chloride, except in the case of J. W. who was still undergoing a mercurial diuresis.

Body fluids and the concentration of serum sodium. Extracellular volume (chloride space) was expanded from 0.2 liter to 1.9 liters (in five of the seven patients the expansion exceeded 1 liter) shortly after cessation of the glucose infusion (Balance period $A$, Table II). The magnitude of this expansion was greater than could be accounted for by retention of injected or ingested fluid. In the three thirsting patients (A. B., T. L., J. W.), the increase in extracellular volume seemed to exceed the total amount of injected water, even if the water intake is not corrected for the greatly accelerated urine flow. Therefore, the expanded extracellular volume after the injections of glucose was dependent upon a transfer of water from cells into the extracellular fluid.

The concentration of serum sodium fell by 7 to $20 \mathrm{mEq} . / \mathrm{L}$ at the end of the infusion of glucose. This fall was not the result of augmented excretion of sodium in the urine, since the concentration of sodium in the urine was far below that of serum. Although a transfer of sodium into cells (Table II) could account for part of the depression of the serum sodium, it should be emphasized that the error inherent in estimations of cellular transfers of sodium on the basis of alterations in the chloride space may be large (9). This is true not only because of the fact that sodium is

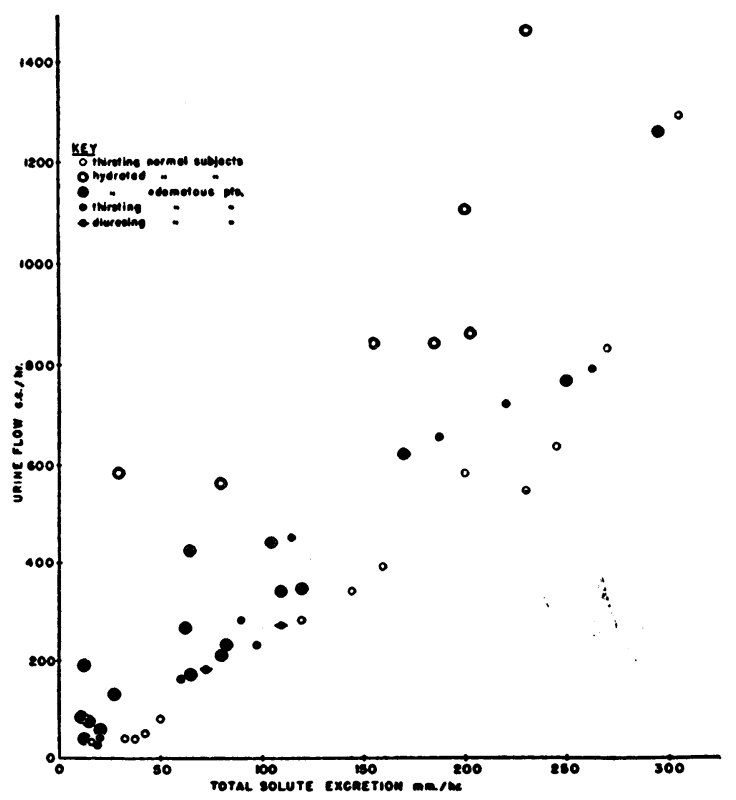

Fig. 3. The Relationship between the Excretion of Total Solutes and Urine Flow during Glucose Diuresis in Various Subjects

See legend of Figure 1 for significance of semi-solid circle with horizontal bar. 
present principally in the extracellular fluid in high concentration, but also because of the probability that the chloride space is not precisely equivalent to extracellular volume $(10,11)$. Hence, comparatively slight errors in the measurement of changes in the extracellular volume, as well as in the chemical analyses, could result in large calculated transfers. This possibility of magnifying small errors by multiplication with large numbers is especially likely in the present study, since chloride space was assumed to be almost twice normal. Therefore, the error of the estimated movement of sodium into or out of cells would, other things being equal, be almost twice as great as that in a normal subject. It is probable, therefore, that the fall in the concentration of serum sodium was principally a result of dilution of the extracellular fluid by cell water (Table II) withdrawn from the intracellular phase by the marked increase in the effective osmotic pressure of the extracellular fluid produced by hyperglycemia.

As hyperglycemia receded, the effective osmotic pressure of extracellular fluid fell sharply, and the concentration of serum sodium rose to values approaching those of the control period. This rise in sodium concentration was probably a sequel of the return of water to the intracellular phase (Table II) in response to the new osmotic gradient.

Occasional discrepancies between estimated changes in effective osmotic pressure (Table I) and changes in intracellular volume (Table II) were noted. Although it may be tempting to invoke possible alterations in osmotic activity of components of the cellular phase to explain away these disparities, it is likely that these apparent changes in intracellular activity reflect cumulative chance errors in chemical methods and in the assumptions inherent in the methods of calculation.

Plasma volume, estimated from changes in hematocrit and hemoglobin values (Tables I and II) expanded during the infusion and contracted subsequently. Extreme changes in plasma volume seem to have occurred during certain periods, but these probably illustrate the crude nature of this measure of change in plasma volume. It is also possible that these apparent changes of plasma volume represent, in part, temporary shifts of interstitial fluid into and from the vascular compartment presumably as a result of transient diffusion gradients of glucose.
Excretion of salt and water. Rapid injection of 600-1200 cc. of hypertonic glucose resulted in massive glycosuria (up to $39 \mathrm{gm}$. or $218 \mathrm{mM} / \mathrm{hr}$.) and marked acceleration of urine flow (Table I). In only one subject (A. B.), however, did the volume of urine excreted following administration of glucose exceed the intake of water. If extrarenal losses of water were of the order of $40 \mathrm{cc}$. $/ \mathrm{hr}$., the water balances of the other patients either approached zero or were frankly positive. Despite the fact that the excretion of sodium increased appreciably when glycosuria occurred, significant quantities of the ion were excreted by only two patients (J. W. and L.), mentioned above, who were already delivering their edema.

Transfers and excretion of potassium and phosphorus. The concentration of serum potassium fell in all patients except $\mathrm{L}$. and $\mathrm{J}$. W. from 0.1 to $1.4 \mathrm{mEq} . / \mathrm{L}$ at the completion of the glucose infusion, and remained depressed (M. S.) or fell further (all other cases) in the subsequent periods (Table I). Balance data (Table II) indicate that in a majority of periods this fall was attributable primarily to a rate of liberation of potassium from cells which was diminished when compared with the control period, or to a net movement of potassium into cells, in conjunction with the utilization of glucose. In these patients, as in normal subjects (1), this movement of potassium toward cells counteracted the usual tendency for cells to discharge potassium to preserve a constant serum concentration in the face of increased urinary excretion and expanding extracellular volume. The excretion of potassium was augmented by the glucose infusion in all patients.

Changes in the concentration of serum inorganic phosphate usually paralleled those of serum potassium, particularly at the completion of the infusion (Table I). This parallelism was also evident during period $B$ of experiments 4 through 7 , but marked discrepancies are obvious in experiments 1,2 , and 3 . When the concentration of serum phosphate fell, its excretion increased and the estimated rate of liberation of the ion from body cells usually decreased. A net movement of phosphate into cells could be demonstrated in seven of the 14 balance periods (Table II). But the rate of release of phosphate from cells appeared to increase (above that of the control period) during six of the balance periods despite accelerated utili- 
zation of glucose. Accelerated utilization and storage of carbohydrate, therefore, does not necessarily provoke net cellular retention of phosphate. For example, during certain periods of increased utilization of glucose (Experiments 1-B, 3-B, 4-B, Table II), the concentration of serum phosphate rose despite augmented excretion of the ion. Since contraction of extracellular volume did not fully account for this rise in concentration, it may have been related, in part, to transfer of phosphate from the cellular phase. That the net movement of phosphorus may be away from cells is not, of course, evidence of a failure of participation of inorganic phosphate in carbohydrate metabolism, since striking alterations of the distribution of intracellular components may take place without necessary reflection in overall measurements.

\section{DISCUSSION}

The failure of rapid injections of large quantities of hypertonic glucose to provoke appreciable depletion of augmented stores of water and salt indicated that such injections were of little or no value in the treatment of the edema of these patients. This is in accord with other observations $(12,13)$, although detailed studies of rapid administration of comparable amounts of hypertonic glucose in edema have not been reported previously. It seems probable that the paucity of such studies is at least in part a reflection of a prevalent fear that patients with edema, particularly if it is secondary to heart failure, withstand parenteral fluids poorly as a result of a predisposition to pulmonary edema under these circumstances. Despite extremely rapid expansion of plasma and extracellular volume, one transient episode of increased dyspnea (in a cirrhotic) was the sole respiratory complication. Although solutions of sodium salts might not have been so innocuous under the same conditions, the present study indicated that certain fluids could be given parenterally to edematous patients with greater safety than is sometimes assumed.

Cellular dehydration contributed considerably to the expansion of extracellular volume induced by the infusions of glucose (Table II). This transfer of water from cells could not have occurred if glucose traversed cellular membranes freely, because it would then have elevated the osmotic pressure on both sides of the membrane equally and could not have affected the distribution of water. Hence, free glucose must be largely confined to the extracellular fluid, either because it diffuses into cells slowly or because its penetration is not by diffusion but by an active process involving its metabolic transformation within the cell. This latter would seem the more likely alternative, since not only have direct analyses of skeletal and heart muscles in animals and man demonstrated that free glucose is largely confined to the fraction of muscle water which is extracellular $(14,15)$, but radioactive glucose has a volume of distribution which seems to approximate extracellular volume (16).

Changes in the volume of the extracellular fluid and the concentration of serum sodium in edematous patients were similar to those noted in normal subjects following similar glucose loads (1). But the renal response to these distortions of the internal environment differed markedly in the two groups (Table I, Figure 1). In normal subjects sodium excretion increased two- to eight-fold during massive glycosuria. In five of seven edematous patients reported here, although the relative increase in sodium excretion was far greater than in normal subjects, the absolute amounts of sodium lost were trivial because the excretion of sodium initially was negligible. A massive glycosuria of $205 \mathrm{mM}$ / $\mathrm{hr}$. in the case of A. B., although increasing sodium excretion 50-fold, resulted in an excretion of only $1.0 \mathrm{mEq} . / \mathrm{hr}$. because the initial rate was 0.02 $\mathrm{mEq} . / \mathrm{hr}$.

Since measurements of clearances of mannitol and of para-aminohippurate were at about the normal range in the two patients (A. B. and T. L.) in whom salt retention was most tenacious, it is difficult to ascribe such abnormalities of sodium excretion to gross disturbances in renal hemodynamics (7). Nor was there some intrinsic abnormality in the kidneys of the edematous patients which precluded the salt diuresis usually elicited by glycosuria : when circumstances promoting salt retention were altered by bed rest and digitalis (L.), then glycosuria swept salt into the urine in large amounts, as in normal subjects (Figure 1). Initial hyponatremia and antecedent intake low in sodium do not appear to account for the failure of glucose to sweep out large quantities of salt in these patients as contrasted to normal subjects (1). In the latter, striking diminution in concentration of serum sodium after administration of 
glucose did not prevent excretion of relatively large quantities of sodium. Moreover, antecedent saltfree diets do not, in normal subjects, prevent the diuresis of salt (17). And finally, marked augmentation of salt excretion is observed during diabetic acidosis when analogous glucose loads are present in patients who are free of edema, but whose intake of salt has necessarily been curtailed (18). Nevertheless, the data suggest that the renal response to administered glucose is not necessarily a function of the filtered glucose or sodium, but varies with those influences in the internal environment which condition tubular activity (19, 20).

The accelerated urinary losses of salt accompanying glycosuria have frequently been considered a purely passive consequence of the osmotic pressure of the nonreabsorbed solute within the renal tubule. The fraction of filtered glucose which is excreted in the urine, by restraining the reabsorption of water in the proximal tubules, is thought to augment the excretion of salt, either by accelerating its passage through the tubules $(21,22)$ or by diluting the concentration of tubular sodium below that of extracellular fluid $(4,5,23)$. The failure of a massive glycosuria, in absolute terms, significantly to augment sodium excretion in these patients militates strongly against any rigid interpretation of this hypothesis. If the capacity of the tubular system for sodium transport were fixed, then such a hypothesis could not account for the negligible losses of sodium observed in most of the patients reported here. On the other hand, if the capacity for tubular transport is variable, largely conditioned by factors in the internal environment, then the concept of a Tm for sodium loses much of its meaning. This does not, of course, imply that there is no intrinsic tubular mechanism for sodium transport which may be influenced by the character and flow of tubular urine, as has been pointed out $(22,24)$. However, such observations as the failure of a sulfate diuresis to sweep out sodium chloride $(25,26)$, the variable response to urea loads $(1,2,6,23)$, and the cutback in sodium excretion in some diabetic patients despite continued massive glycosuria $(18,27,28)$, suggest that the osmotic influence of the injected solute within the renal tubule may be only one of several determinants. This view is, on the whole, consonant with that expressed in greater detail by Wolf (29).
In Figures 2 and 3 the excretion rates of glucose and of total solutes are plotted against urine flow, both for the patients of this study and for the normal subjects of a previous report (1). The excretion of water per unit of excreted glucose or total solutes was considerably increased by hydration in the normal subject, but was slightly, if at all, changed by hydration in our edematous patients. This undoubtedly reflected the usual difficulty in obtaining a water diuresis in edematous patients. Among the hydropenic normal and edematous subjects, the excretion of water per unit of excreted glucose was about the same for both groups. Although there is a suggestion that hydropenic edematous patients excrete slightly more water per mole of total urinary solutes than hydropenic normal subjects, there is too much overlap in the two groups to permit this conclusion.

The accelerated excretion of potassium in the face of declining serum values in the hydropenic subjects of this report has been: observed under similar conditions in normal subjects and may have been a result of cellular dehydration, in keeping with previously expressed views on this subject $(1,30-32)$. The precise nature of the relationship of dehydration to excretion of potassium is, however, obscure. But the results in the hydrated patients, in each of whom there was an overall positive balance of total body water, as well as accelerated excretion of potassium, confirm the emphasis placed on intracellular dehydration as a salient determinant of this urinary loss of potassium. The fact that excretion of potassium was not increased in hydrated normal subjects (1), but was augmented in hydrated edematous patients, is unexplained.

The cause of severe, painful muscular spasm which developed in the hydropenic patients about one hour after cessation of the infusion and persisted for several hours is not clear. Since symptoms and signs did not appear in hydrated patients, and ingestion of water probably did in some measure prevent cellular dehydration, the latter may have been a prominent factor in the genesis of these symptoms. If this is the case, edematous subjects must have an additional obscure peculiarity in this respect, since comparable injections of glucose failed to evoke these complications in normal dehydrated subjects (1). Nor does the temporal 
sequence provide clear-cut support of this hypothesis, since symptoms were most intense when hyperglycemia had receded and the concentration of serum sodium had been restored. There were no clinical features of tetany and the serum calcium of A. B., although slightly depressed to $7.21 \mathrm{mg}$. \% at the end of the glucose infusion, after an initial value of $8.59 \mathrm{mg}$. \%, subsequently rose to $8.52 \mathrm{mg}$. $\%$ when symptoms had appeared. Nor can these spasms be reasonably attributed to disturbances in metabolism of other electrolytes studied during these experiments. The cramps resembled those described in the condition known as heat cramps (33) or cramps developing during salt depletion when there is free access to water (34). Such cramps have been related to relative intracellular overhydration in conjunction with salt depletion and replacement by water without salt (33). In the present study, however, the concomitant changes in salt and water metabolism differed significantly: There was no remotely comparable depletion of salt and water; there was overexpansion of the extracellular phase and intracellular dehydration; the cramps were obviated by ingestion of water.

It may be significant that the five patients with initially diminished concentrations of serum sodium, and consequent hypotonicity, excreted far less sodium following administration of glucose than did the other two patients (J. W. and L.) in whom the concentration of serum sodium was normal. A similar observation has been made in a study of the retention of administered hypertonic saline by cirrhotics with ascites (7), and is in keeping with the concept $(35,36)$ that abnormal reduction of the osmotic pressure of body fluids and diminution of the concentration of serum sodium are important features of intractable edema. On the other hand the initially normal values of serum sodium and of osmolar concentration in J. W. and L. may have been the consequence of a prior diuresis induced by other factors (see Procedure). The data suggest that a normal concentration of serum sodium as well as a normal osmotic pressure may be related to the initiation and maintenance of a diuretic response.

\section{SUMMARY}

1. Six hundred to $1200 \mathrm{cc}$. of $25 \%$ glucose were administered intravenously over 30 to 90 minutes to three patients with cardiac edema, and four with edema caused by hepatic cirrhosis. Water was given by mouth to four subjects and withheld from three.

2. Urine flow was greatly augmented but losses of water did not exceed the volume of fluid administered. Excretion of sodium, potassium, phosphorus, and chloride usually rose temporarily, as massive glycosuria developed, and then fell. The diuresis of sodium, however, was usually too small to produce appreciable reduction of increased stores of sodium.

3. Concentrations of serum sodium diminished sharply by as much as $20 \mathrm{mEq}$./L and subsequently returned toward control values. This diminution was apparently produced by extracellular expansion resulting from cellular dehydration attributable to hyperglycemia and attendant increase of effective extracellular osmotic pressure.

4. Serum potassium fell progressively, by as much as $2.2 \mathrm{mEq}$./L in five patients during initial expansion and despite later contraction of extracellular volume (chloride space). This fall was frequently associated with apparent transfer of potassium into cells, presumably in relation to accelerated utilization and storage of carbohydrate.

5. Aside from increased dyspnea in one patient, severe muscular cramps were the sole complication observed. These occurred exclusively in the patients given glucose without supplementary intake of water and could not be definitely ascribed to changes in concentration of serum electrolytes or to the state of cellular hydration.

6. Findings are discussed in relation to current theories of the nature of "osmotic" diuresis and of the formation of edema.

7. The development of muscular spasms together with the trivial net losses of water and salt suggest that glucose, and probably similar loading substances as well, are of little value in the treatment of intractable edema.

\section{REFERENCES}

1. Seldin, D. W., and Tarail, R., Effect of hypertonic solutions on metabolism and excretion of electrolytes. Am. J. Physiol., 1949, 159, 160.

2. Rapaport, S., West, C. D., and Brodsky, W. A., Excretion of solutes and osmotic work during osmotic diuresis of hydropenic man. The ideal and the proximal and distal tubular work; the biological maximum of work. Am. J. Physiol., 1949, 157, 363. 
3. Relman, A. S., Goodyer, A. V. N., and Peterson, E. R., The effect of mannitol on salt excretion during water diuresis. J. Appl. Physiol., 1949, 1, 601.

4. Wesson, L. G., Jr., Anslow, W. P., Jr., and Smith, H. W., The excretion of strong electrolytes. Bull. N. Y. Acad. Med., 1948, 24, 586.

5. Wesson, L. G., Jr., and Anslow, W. P., Jr., Excretion of sodium and water during osmotic diuresis in the dog. Am. J. Physiol., 1948, 153, 465.

6. Cizek, L. J., and Holmes, J. H., Chloride excretion during osmotic diuresis in the dog. Am. J. Physiol., 1950, 160, 536.

7. Goodyer, A. V. N., Relman, A. S., Lawrason, F. D., and Epstein, F. H., Salt retention in cirrhosis of the liver. J. Clin. Invest., 1950, 29, 973.

8. Elkinton, J. R., Danowski, T. S., and Winkler, A. W., Hemodynamic changes in salt depletion and in dehydration. J. Clin. Invest., 1946, 25, 120.

9. Elkinton, J. R., Winkler, A. W., and Danowski, T. S., Inactive cell base and the measurement of changes in cell water. Yale J. Biol. \& Med., 1944, 17, 383.

10. Heilbrunn, L. V., and Hamilton, P. G., The presence of chloride in muscle fibers. Physiol. Zool., 1942, $15,363$.

11. Burch, G. E., Threefoot, S. A., and Ray, C. T., Rates of turnover and biologic decay of chloride and chloride space in the dog determined with the long-life isotope $\mathrm{Cl}^{\text {*⿻ }}$. J. Lab. \& Clin. Med., 1950, $35,331$.

12. Crutchfield, A. J., Jr., and Wood, J. E., Jr., Urine volume and total renal sodium excretion during water diuresis. Ann. Int. Med., 1948, 28, 28.

13. Brown, W. E., and Bradbury, J. T., The effectiveness of various diuretic agents in causing sodium excretion in pregnant women. Am. J. Obst. \& Gynec., 1948, 56, 1.

14. Cori, G. T., Closs, J. O., and Cori, C. F., Fermentable sugar in heart and skeletal muscle. J. Biol. Chem., 1933, 103, 13.

15. Trimble, H. C., and Cary, B. W., Jr., On the true sugar content of skin and muscle in diabetic and non-diabetic persons. J. Biol. Chem., 1931, 90, 655.

16. Wick, A. N., Drury, D. S., and Mackay, E. M., Glucose space of the body. Am. J. Physiol., 1950, 163, 224.

17. Unpublished observations.

18. Seldin, D. W., and Tarail, R., The metabolism of glucose and electrolytes in diabetic acidosis. J. Clin. Invest., 1950, 29, 552.
19. Peters, J. P., The role of sodium in the production of edema. New England J. Med., 1948, 239, 353.

20. Peters, J. P., Sodium, water and edema. J. Mt. Sinai Hosp., 1950, 17, 159.

21. Shannon, J. A., Urea excretion in the normal dog during forced diuresis. Am. J. Physiol., 1938, 122, 782.

22. Goodyer, A. V. N., and Glenn, W. W. L., The excretion of solutes injected into the renal artery of the dog. To be published.

23. Mudge, G. H., Foulks, J., and Gilman, A., Effect of urea diuresis on renal excretion of electrolytes. Am. J. Physiol., 1949, 158, 218.

24. Berliner, R. W., Renal excretion of water, sodium, chloride, potassium, calcium and magnesium. Am. J. Med., 1950, 9, 541.

25. Schwartz, B. M., Smith, P. K., and Winkler, A. W. Renal excretion of sulfate. Am. J. Physiol., 1942, 137, 658.

26. Wolf, A. V., and Ball, S. M., Effect of intravenous sodium sulfate on renal excretion in the dog. Am. J. Physiol., 1950, 160, 353.

27. Atchley, D. W., Loeb, R. F., Richards, D. W., Benedict, E. M., and Driscoll, M. E., On diabetic acidosis. J. Clin. Invest., 1933, 12, 297.

28. Kerpel-Fronius, E., Zur Frage des diabetischen Salzmangelzustandes. Klin. Wchnschr., 1937, 16, 1466.

29. Wolf, A. V., The Urinary Function of the Kidney. Grune and Stratton, New York, 1950.

30. Elkinton, J. R., and Winkler, A. W., Transfers of intracellular potassium in experimental dehydration. J. Clin. Invest., 1944, 23, 93.

31. Mudge, G. H., Foulks, J., and Gilman, A., Renal secretion of potassium during cellular dehydration. Am. J. Physiol., 1950, 161, 159.

32. Danowski, T. S., Newer concepts of the role of potassium in disease. Am. J. Med., 1949, 7, 525.

33. Ladell, W. S. S., Heat cramps. Lancet, 1949, 2, 836.

34. McCance, R. A., Experimental sodium chloride deficiency in man. Proc. Roy. Soc., London, 1936, s. B., 119, 245.

35. Sims, E. A. H., Welt, L. G., Orloff, J., and Needham, J JWW., Asymptomatic hyponatremia in pulmonary tuberculosis. J. Clin. Invest., 1950, 29, 1545.

36. Luetscher, J. A., Jr., and Deming, Q. B., Treatment of nephrosis with cortisone. J. Clin. Invest., 1950, 29, 1576. 